\title{
Analisis faktor-faktor yang mempengaruhi pertumbuhan ekonomi di Provinsi Riau tahun 2000-2018
}

\author{
Miftakul Khoiri*1, Syapsan², \& Sri Endang Kornita² \\ ${ }^{1}$ Bank Indonesia, Kantor Cabang Pekanbaru, Indonesia \\ 2Pascasarjana Ilmu Ekonomi, Universitas Riau, Indonesia
}

\begin{abstract}
Abstrak Terdapat beberapa permasalahan yang berbeda pada sumber daya di setiap daerah, yaitu investasi, tenaga kerja dan teknologi sebagai faktor pembentuk output perekonomian daerah. Penelitian ini menganalisis hubungan antara investasi dalam bentuk Penanaman Modal Asing (PMA), Penanaman Modal Dalam Negeri (PMDN), belanja modal pemerintah, angkatan kerja dan ekspor dengan pertumbuhan ekonomi. Tujuan penelitian adalah melihat pengaruh besarnya faktor-faktor tersebut terhadap Pertumbuhan ekonomi di Provinsi Riau 200o-2018. Untuk kepentingan khusus penelitian dengan tujuan melihat pengaruh krisis keuangan global tahun 2008 terhadap pertumbuhan ekonomi maka dimasukkan variabel dummy krisis keuangan. Penelitian ini adalah penelitian kuantitatif dengan metode regresi berganda log-log linier dan data time series. Model diestimasi dengan metode Ordinary Least Square (OLS). Hasil penelitian menunjukkan bahwa PMA, PMDN, angkatan kerja dan ekspor signifikan positif mempengaruhi pertumbuhan ekonomi yang diukur dengan nilai Produk Domestik Regional Bruto (PDRB). Begitu juga dengan dummy krisis keuangan global meskipun berlangsung singkat ternyata berpengaruh terhadap PDRB di Provinsi Riau. Namun demikian ditemukan bahwa belanja modal pemerintah tidak signifikan mempengaruhi pertumbuhan PDRB.
\end{abstract}

Kata kunci: krisis keuangan global; pertumbuhan ekonomi; log-log linier; time series

\begin{abstract}
There are some problems in resources of the regions, namely investment, labour force, and technology as the component factors to make the output of the region's economy. This study aims to analyze the relationship between investment as consist of foreign direct investment (FDI), private investment, government capital expenditure, labour force, export and economic growth to the gross regional domestic product growth of regency in Riau Province 2000-2018. For the specific purpose of describing global financial crises in 2008 influence the economic growth, we put the dummy variable of the financial crisis in the model. This research is quantitative descriptive with the multiple regression model of loglinear and time series method using Ordinary Least Square (OLS). The study shows that government capital expenditure is statistically not significant to affect the gross regional domestic product growth. FDI, private investment, labour force and export is statistically significant to affect the gross regional domestic product growth. As well as a dummy of the global financial crisis is statistically significant to affect the gross regional domestic product growth.
\end{abstract}

Keywords: global financial crisis; economic growth; log-linear model; time series

JEL Classification: $\mathrm{E2O}$; $\mathrm{O} 4 \mathrm{O} ; \mathrm{C}_{3} 2$

\footnotetext{
* Penulis koresponden 


\section{PENDAHULUAN}

Pembangunan perekonomian suatu daerah pada dasarnya merupakan suatu proses perencanaan pembangunan ekonomi daerah secara bertahap dalam jangka panjang yang dilakukan oleh pemerintah daerah dan masyarakat dalam mengelola dan mengalokasikan sumber daya yang ada seperti Sumber Daya Alam (SDA), Sumber Daya Manusia (SDM), Sumber Daya Kapital atau Investasi dan Sumber Daya Kelembagaan serta sumber daya lainnya untuk menstimulasi perkembangan baik dari sisi kuantitas maupun kualitas kegiatan ekonomi daerah. Salah satu indikator untuk mengetahui proses pembangunan perekonomian daerah dapat dilihat pada angka pertumbuhan ekonomi, dengan demikian pertumbuhan ekonomi merupakan bagian dari pembangunan ekonomi itu sendiri. Untuk mengukur pertumbuhan ekonomi, para ekonom menggunakan data Produk Domestik Bruto (PDB), yang mengukur pendapatan total dari setiap orang dalam perekonomian atau dengan cara lain yaitu menghitung pengeluaran total atas output barang dan jasa dalam perekonomian. Untuk kasus pertumbuhan ekonomi daerah atau regional maka dapat digunakan data Produk Domestik Regional Bruto (PDRB) baik dengan pendekatan produksi, pendekatan pengeluaran/penggunaan maupun pendekatan pendapatan.

Kondisi umum perekonomian Provinsi Riau Tahun 2018 sebesar 2,34\% (YoY) tumbuh lebih lambat jika dibandingkan 2017 sebesar 2,71\% (YoY). Perubahan pertumbuhan Riau yang turun ini di bawah pertumbuhan ekonomi wilayah Sumatera yang tumbuh dari 4,30\% (YoY) menjadi 4,53\% (YoY) pada Tahun 2018. Sedangkan pertumbuhan ekonomi tahunan secara nasional juga di atas pertumbuhan ekonomi Riau yang mengalami peningkatan dari $5,07 \%$ menjadi $5,17 \%$ pada 2018 . Selama 8 tahun terakhir pertumbuhan ekonomi Riau di bawah Sumatera dan Nasional.

Pembentukan modal, konsumsi, tenaga kerja dan ekspor merupakan faktor penentu dalam pembentukan PDRB yang berperan besar dalam pertumbuhan ekonomi daerah. Pada penelitian ini, istilah belanja modal pemerintah, belanja pemerintah dalam pembangunan infrastruktur, belanja modal publik, investasi pemerintah, investasi publik, mempunyai arti yang sama. Menurut Kuncoro (2004), konsumsi pemerintah daerah dalam bentuk belanja pembangunan yang dikeluarkan oleh pemerintah daerah berpengaruh positif terhadap perekonomian daerah. Belanja pembangunan di sini meliputi pengadaan dan perbaikan fasilitas pendidikan, kesehatan, dan sarana penunjang lainnya. Dengan ditambahnya infrastruktur dan perbaikan infrastruktur yang ada oleh pemerintah daerah tentunya akan meningkatkan perekonomian di daerah.

Perekonomian secara umum mengalami fluktuasi jangka pendek pada aktivitas ekonomi, di ukur dengan Gross Domestic Product (GDP). Fluktuasi ini berkaitan dengan pergerakan di berbagai variabel makroekonomi. Secara khusus ketika pertumbuhan GDP turun, pertumbuhan konsumsi juga turun (biasanya dengan jumlah yang lebih kecil) demikian juga dengan investasi (biasanya dengan jumlah yang lebih besar) dan tingkat pengangguran naik. Meskipun ekonom menggunakan berbagai indikator petunjuk untuk memprediksi fluktuasi ini, fluktuasi tersebut tetap sulit untuk diramalkan (Mankiw, 2012). Sejalan dengan pendapat tersebut maka 
faktor yang mungkin dominan mempengaruhi pertumbuhan ekonomi daerah adalah investasi, konsumsi pemerintah dalam bentuk belanja pembangunan, angkatan kerja dan konsumsi rumah tangga.

Konsumsi rumah tangga secara kuantitas mengalami peningkatan setiap tahunnya namun persentase peningkatannya berfluktuasi setiap tahun. Hal ini mengindikasikan bahwa relatif kurang stabilnya tingkat pendapatan rumah tangga sehingga menyebabkan terjadinya perubahan terhadap total konsumsi rumah tangga. Selanjutnya jika dikaitkan antara konsumsi rumah tangga dengan perekonomian daerah terlihat bahwa perubahan pada tingkat konsumsi rumah tangga hampir sebanding dengan perubahan perekonomian daerah. Sebagai bukti bahwa pada tahun 2015 dan tahun 2016 terlihat persentase peningkatan dari konsumsi rumah tangga seiring dengan persentase peningkatan dari perekonomian daerah yang lebih kecil dari tahun sebelumnya.

Investasi swasta secara kuantitas mengalami penurunan terus menerus dari tahun 2015-2018 tetapi persentase perubahannya mengalami perubahan yang berfluktuasi. Namun pada tahun 2017 terjadi penurunan terbesar dari jumlah investasi swasta sebesar $7,70 \%$. Terjadinya penurunan investasi swasta ini tentunya sangat tidak diharapkan karena idealnya investasi swasta tersebut harus mengalami peningkatan setiap tahun agar dapat memberikan kontribusi terhadap perekonomian daerah. Jika dilihat hubungan investasi swasta dengan perekonomian daerah, terlihat bahwa penurunan yang terjadi selama 3 tahun terakhir juga menyebabkan terjadi penurunan persentase pertumbuhan perekonomian daerah.

Belanja pembangunan yang dialokasikan oleh pemerintah Provinsi Riau pada tahun 2010-2013 secara kuantitas mengalami peningkatan namun persentase peningkatannya mengalami penurunan setiap tahunnya. Namun di awal tahun 2015 Pemerintah Provinsi Riau berupaya meningkatkan belanja modal pembangunan setelah terjadi penurunan yang luar biasa pada tahun 2014 yang hampir mencapai $72 \%$. Jika belanja modal pembangunan dikaitkan dengan perekonomian daerah maka masalah yang terlihat yaitu pada tahun 2017 terjadi penurunan yang cukup tajam dari belanja modal pembangunan dan begitu juga dengan perekonomian daerah Provinsi Riau.

Variabel lain yang turut berkontribusi bagi pertumbuhan ekonomi regional adalah tenaga kerja. Kondisi ketenagakerjaan Provinsi Riau pada Agustus 2017 menunjukkan penurunan yang relatif sangat kecil yaitu sebesar $0,7 \%$ dan justru meningkat positif cukup besar di tahun 2018 menjadi 4,8\%. Namun sejumlah indikator ketenagakerjaan memperlihatkan terjadinya peningkatan kualitas ketenagakerjaan antara lain menurunnya angka Tingkat Pengangguran Terbuka (TPT) Riau dari 7,43\% pada Agustus 2016 menjadi 6,22\%. Posisi Agustus 2018 menunjukkan bahwa 3,11 juta atau $65,23 \%$ dari 4,70 juta jiwa penduduk Riau dengan usia 15 tahun ke atas merupakan angkatan kerja (Bank Indonesia, 2019).

Religi dan Purwanti (2017) dengan menggunakan model standar pertumbuhan ekonomi Solow-Swan menemukan bahwa PMA, belanja modal pemerintah dan tenaga kerja berpengaruh positif dan signifikan terhadap pertumbuhan PDRB 
kabupaten dengan tipe Klassen I. Hasil temuan serupa sejalan dengan penelitian Salebu (2014), yang menyatakan bahwa penanaman modal asing atau Foreign Direct Investment (variabel LFDI) berpengaruh signifikan terhadap pertumbuhan ekonomi (LGDP) melalui pendekatan model fungsi produksi Cobb-Douglas. Su dan Liu (2016) menemukan hasil empiris bahwa Penanaman Modal Asing (FDI) dan modal sumber daya manusia pada fungsi Aggregate Solow berdampak positif dan signifikan pada peningkatan output perekonomian di China.

Selain itu, Mankiw, Romer, dan Weil seperti yang dikutip dalam McQuinn dan Whelan (2007), Ishise dan Sawada (2009), dan Oluwatobi dan Ogunrinola (2011) memperluas atau melakukan modifikasi model pertumbuhan ekonomi Solow dengan menambahkan variabel eksogen pada fungsi standar Aggregate Solow. Variabel eksogen tersebut tidak hanya berupa kemajuan dan perilaku teknologi namun juga berupa variabel eksogen modal sumber daya manusia (human capital), pendidikan, kesehatan, penelitian dan pengembangan, modal sosial, resource endowment, iklim, kelembagaan dan lainnya yang berkontribusi bagi output perekonomian atau pertumbuhan ekonomi sehingga model ini dikenal dengan model Mankiw, Romer dan Weil (MRW model) atau Augmented Solow Model.

Berdasarkan kajian teori pertumbuhan ekonomi dimaksud maka untuk kasus Riau digunakan variabel realisasi PMA, PMDN, jumlah angkatan kerja, pengeluaran pemerintah daerah, ekspor di provinsi Riau dan dummy krisis keuangan global dalam kaitannya dengan pertumbuhan atau perkembangan ekonomi Provinsi Riau. Untuk itu identifikasi pokok masalah yang akan dikaji dalam penelitian ini adalah apakah variabel investasi swasta dalam bentuk PMA dan PMDN, belanja langsung modal pemerintah, angkatan kerja dan ekspor berpengaruh terhadap pertumbuhan ekonomi Provinsi Riau 2000-2018.

\section{METODOLOGI PENELITIAN}

\section{Model Penelitian}

Model yang digunakan dalam penelitian ini adalah persamaan dasar non linier yang diadopsi dari teori pertumbuhan ekonomi Solow yang dimodifikasi dengan variabel eksogen ekonomi makro Keynes dan beberapa penelitian empiris sebelumnya untuk mengembangkan model determinasi atau penentuan output agregat dengan dekomposisi dalam pengertian Produk Domestik Bruto (PDB atau GDP) dari pendekatan pengeluaran.

Spesifikasi model dasar berangkat dari model pertumbuhan ekonomi Neo Klasik Solow (Neoclassical Growth Model) dengan fungsi agregat standar:

$$
Y=A^{e \mu t} \cdot K^{\alpha} \cdot L^{1-\alpha}
$$

$\mathrm{Y}=$ Produk Domestik Bruto

$\mathrm{K}=$ Stok modal fisik dan modal manusia

$\mathrm{L}=$ Tenaga kerja non terampil

$\mathrm{A}=$ Konstanta yang merefleksikan tingkat teknologi dasar

$\mathrm{e}^{\mu \mathrm{t}}=$ Melambangkan tingkat kemajuan teknologi 


\section{$\alpha=$ Melambangkan elastisitas output terhadap model yakni persentase kenaikan PDB yang bersumber dari $1 \%$ penambahan modal fisik dan modal manusia.}

Selanjutnya, dilakukan modifikasi sesuai teori pertumbuhan atau perkembangan ekonomi agregat (Augmented Solow Growth) untuk permasalahan perkembangan ekonomi Provinsi Riau yang diukur dari PDRB dengan pendekatan pengeluaran (PDRB by Expenditure) sebagai (Y/PDRB), pertumbuhan stok modal dilihat melalui Investasi Swasta Asing (PMA/FDI) sebagai (X1), Investasi Swasta Dalam Negeri (PMDN) sebagai (X2), Angkatan Kerja (AK) sebagai (X3), Government Expenditure dilihat dari Pengeluaran Langsung Modal Pembangunan Pemerintah Provinsi (BLMP) sebagai (X4), Ekspor dilihat dari ekspor Provinsi Riau (XPOR) sebagai (X5) dan ditambah variabel dummy Krisis Keuangan Global sebagai (DKK) sebagai (Dt) sehingga diperoleh persamaan PDRB:

$$
Y t=f(P M A t, P M D N t, A K t, B L M P t, X P O R t, D K K t)
$$

Dari persamaan (1) dan (2) diperoleh model Augmented Solow Growth (MRW Solow Growth):

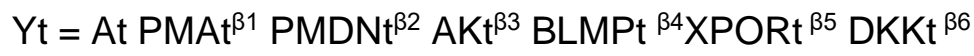

Keterangan:

Yt $=$ Perekonomian Daerah (PDRB dari sisi pengeluaran periode ke-t dalam miliar Rp)

PMAt = Realisasi Penanaman Modal Asing (PMA) periode ke-t dalam ribu USD)

AKt $=$ Angkatan Kerja periode ke-t dalam ribu orang

PMDNt = Realisasi Penanaman Modal dalam Negeri (PMDN) periode ke-t dalam juta $\mathrm{Rp}$

BLMPt = Total Realisasi Pengeluaran atau Belanja Langsung Modal Pemerintah Provinsi Periode ke-t dalam miliar Rp

$\mathrm{XPORt}=$ Ekspor periode ke-t dalam ribu USD

$\mathrm{DKKt}=$ dummy variable untuk melihat pengaruh krisis keuangan global (DKK)

At $\quad=$ Konstanta

$\beta_{1}, \ldots, \beta_{6}=$ Koefisien (parameter yang diestimasi)

$\mathrm{t} \quad=$ Periode waktu penelitian time series ke- $\mathrm{t}$

Untuk memperoleh linier dari bentuk persamaan (3) maka persamaan tersebut dilinearkan dengan menggunakan bentuk log-log linear/double log linear (Gujarati, 2010), sehingga diperoleh persamaan (4):

$L_{-} Y t=\beta 0+\beta_{1} L_{-} P M A \$ t+\beta 2 L_{-} P M D N t+\beta_{3} L_{-} A K t+\beta_{4} L_{-} B L M P t+\beta 5 L_{-} X P O R \$ t+$ $\beta 6 D K K t+e t$

Selanjutnya model penelitian ini digunakan untuk menyelidiki hubungan antara variabel-variabel bebas (PMAt, PMDNt, AKt, BLMPt, XPORt, DKKt) dan variabel tergantung $(\mathrm{Yt})$ berdasarkan data time series dari variabel tersebut selama periode 2000-2018. 


\section{Teknik Analisis}

Dalam mengestimasi model digunakan metode atau teknik estimasi dengan teknik Ordinary Least Square (OLS) untuk menduga parameter persamaan regresi linier berganda. Tahapan-tahapan teknik analisis sebagai berikut: (1) melakukan uji akar unit data/stasioneritas (unit root test) sebelum dilakukan penaksiran parameter karena data time series cenderung tidak stasioner. Uji yang digunakan adalah Uji Dickey Fuller. (2) Menaksir parameter dengan metode OLS menggunakan program software EViews. Setelah didapat model dari OLS maka dilakukan (3) uji statistik terhadap ketepatan model persamaan regresi yang diperoleh (goodness of fit).

\section{Jenis dan Sumber Data}

Jenis data yang digunakan dalam penelitian ini adalah data sekunder selama periode 2000-2018 yang diperoleh dari Biro Pusat Statistik Provinsi Riau, Badan Perencanaan Keuangan dan Anggaran Daerah (BPKAD) Provinsi Riau, Statistik Ekonomi dan Keuangan Indonesia (SEKI) Bank Indonesia, Kementerian Keuangan (Kemenkeu), Badan Koordinasi Penanaman Modal (BKPM) serta sumber lain yang terkait dengan penelitian ini. Tabel 1 menunjukkan satuan dan sumber data yang digunakan.

Tabel 1. Label, Satuan dan Sumber Data Variabel Operasional

\begin{tabular}{|c|c|c|c|}
\hline Variabel & Label Data & Satuan/Sumber & $\begin{array}{l}\text { Kecocokan Tanda } \\
\text { yang Diharapkan } \\
\text { (Expected Sign) }\end{array}$ \\
\hline \multicolumn{4}{|c|}{ Variabel tergantung } \\
\hline $\mathrm{Y}$ & $\begin{array}{l}\text { Produk Domestik Regional Bruto } \\
\text { dengan pendekatan } \\
\text { Pengeluaran (PDRB) Atas Dasar } \\
\text { Harga Konstan }\end{array}$ & Rupiah/BPS & \\
\hline \multicolumn{4}{|c|}{ Variabel bebas } \\
\hline $\mathrm{X} 1$ & PMA & USD/BPS/BKPM/BI & + \\
\hline $\mathrm{x} 2$ & PMDN & $\mathrm{Rp} / \mathrm{BPS} / \mathrm{BKPM} / \mathrm{BI}$ & + \\
\hline $\mathrm{x} 3$ & Angkatan Kerja & orang/BPS & + \\
\hline $\mathrm{X} 4$ & $\begin{array}{l}\text { Pengeluaran Langsung Modal } \\
\text { Pembangunan }\end{array}$ & $\begin{array}{l}\text { Rupiah/BPS/BPKA } \\
\text { D/Kemenkeu }\end{array}$ & + \\
\hline $\mathrm{x} 5$ & Ekspor & USD/BPS/BI & + \\
\hline$D t$ & $\begin{array}{l}\text { Dummy Krisis Keuangan Global } \\
\text { (DKK) }\end{array}$ & Waktu(Tahun)/BI & $+/-$ \\
\hline
\end{tabular}

\section{HASIL DAN PEMBAHASAN}

\section{Hasil Uji}

Bagian empiris dalam penelitian ini akan mengestimasi model data time series untuk mengetahui pengaruh signifikan dari PMA, PMDN, Belanja Modal Pemerintah, Angkatan Kerja, Ekspor dan Krisis Keuangan Global terhadap pertumbuhan 
ekonomi Provinsi Riau dengan pendekatan OLS. Seluruh data pada variabel independen dan dependen yang digunakan dalam regresi dilakukan uji akar unit dengan berpatokan pada nilai batas kritis DF test dan probability nya. Hasil uji akar unit dengan membandingkan probability ( $p$ value) dengan taraf signifikansi $(\alpha)$.

Hasil uji akar menunjukkan data pada tingkat level, semua variabel stasioner karena semua nilai $P$ Value lebih kecil dari taraf nyata $(\alpha)$ yang digunakan atau hasil nilai mutlak t-hitung lebih besar dari nilai kritis sehingga tolak $\mathrm{HO}$ artinya tidak terdapat unit root (stasioner) sehingga tidak perlu dilihat variabel tersebut di tingkat first difference.

Hasil estimasi model persamaan log-log linier berganda diperoleh representative output sebagai berikut:

$\log ($ PDRBHK10 $)=4.899+0.021 \log (P M A \$)+0.024 \log (P M D N)+0.626 \log$

$$
(\mathrm{AK})-0.025 \log (\mathrm{BLMP})+0.145 \log (\mathrm{XPOR} \$)+0.254 \mathrm{DKK} \ldots . . .
$$

Selanjutnya sebelum menginterpretasikan hasil persamaan regresi di atas, dilakukan uji asumsi klasik untuk memperhatikan adanya penyimpanganpenyimpangan asumsi klasik, karena pada hakikatnya jika asumsi klasik tidak dipenuhi maka variabel-variabel yang menjelaskan akan menjadi tidak efisien dan model tidak dapat digunakan sebagai alat prediksi yang baik. Seluruh hasil uji asumsi klasik model regresi linier berganda log-log tidak menemukan adanya penyimpangan asumsi klasik artinya terbebas dari multikolinieritas, heteroskedasitas, autokorelasi dan normalitas. Dengan dipenuhinya asumsi klasik, model OLS akan memiliki sifat ideal sesuai dengan teorema Gauss-Markov (Winarno, 2015). Mengingat data yang digunakan time series maka dilakukan uji korelasi antara variabel bebas yang ditunjukkan tabel 2 dengan metode Klien (Gujarati, 2010) yaitu membandingkan antara $R^{2}$ majemuk dengan $R^{2}$ parsial. Jika $\mathrm{R}^{2}$ majemuk $>\mathrm{R}^{2}$ parsial, maka dapat disimpulkan bahwa model empirik tidak terkena korelasi antar variabel bebas dan sebaliknya, jika $R^{2}$ majemuk $<R^{2}$ parsial maka model empirik terkena gangguan korelasi antar variabel bebas.

Tabel 2.Hasil Uji Korelasi Antara Variabel Bebas dengan Metode Klien

\begin{tabular}{|c|c|c|c|}
\hline Variabel & $R^{2}$ majemuk & $\mathbf{R}^{2}$ parsial & Keterangan \\
\hline $\begin{array}{l}\text { PMA dengan PMDN, } \\
\text { Angkatan Kerja, BLMP } \\
\text { Ekspor dan DKK }\end{array}$ & 0.9852 & 0,4437 & $\begin{array}{l}\mathrm{R}^{2} \text { majemuk }>\mathrm{R}^{2} \text { parsial } \\
\text { (Tidak ada korelasi antar } \\
\text { variabel bebas) }\end{array}$ \\
\hline $\begin{array}{l}\text { PMDN dengan PMA, } \\
\text { Angkatan Kerja, BLMP, } \\
\text { Ekspor dan DKK }\end{array}$ & 0.9852 & 0,4098 & $\begin{array}{l}\mathrm{R}^{2} \text { majemuk }>\mathrm{R}^{2} \text { parsial } \\
\text { (Tidak ada korelasi antar } \\
\text { variabel bebas ) }\end{array}$ \\
\hline $\begin{array}{l}\text { Angkatan Kerja dengan } \\
\text { PMA PMDN, BLMP, Ekspor } \\
\text { dan DKK }\end{array}$ & 0.9852 & 0,5297 & $\begin{array}{l}\mathrm{R}^{2} \text { majemuk }>\mathrm{R}^{2} \text { parsial } \\
\text { (Tidak ada korelasi antar } \\
\text { variabel bebas ) }\end{array}$ \\
\hline $\begin{array}{l}\text { BLMP dengan PMA, } \\
\text { PMDN, Angkatan Kerja, } \\
\text { Ekspor dan DKK }\end{array}$ & 0.9852 & 0,7496 & $\begin{array}{l}\mathrm{R}^{2} \text { majemuk }>\mathrm{R}^{2} \text { parsial } \\
\text { (Tidak ada korelasi antar } \\
\text { variabel bebas ) }\end{array}$ \\
\hline $\begin{array}{l}\text { Ekspor dengan PMA, } \\
\text { PMDN, Angkatan Kerja } \\
\text { BLMP dan DKK }\end{array}$ & 0.9852 & 0,7007 & $\begin{array}{l}\mathrm{R}^{2} \text { majemuk }>\mathrm{R}^{2} \text { parsial } \\
\text { (Tidak ada korelasi antar } \\
\text { variabel bebas ) }\end{array}$ \\
\hline
\end{tabular}

Sumber: Data diolah dengan Eviews 
Dari perhitungan nilai $R S$ quare adalah 0,9852 . Hal ini berarti 98,52 persen perekonomian provinsi Riau dapat dijelaskan oleh variasi dari keenam variabel independen di atas, sedangkan sisanya yaitu 1,48 persen dijelaskan oleh sebabsebab lain di luar model. Variasi dari faktor-faktor yang mempengaruhi perekonomian Riau tersebut antara lain yaitu Angkatan Kerja (AK), Penanaman Modal Dalam Negeri (PMDN), Penanaman Modal Asing (PMA), Pengeluaran Pemerintah Daerah Untuk Belanja Langsung Modal Pembangunan (BLMP), Kinerja Ekspor (XPOR) dan Krisis Keuangan Global (Dt).

Pada uji statistik secara parsial dengan nilai t kritis (critical value) pada $\mathrm{df}=(\mathrm{n}$ $\mathrm{k}$ ), dimana $\mathrm{n}$ adalah jumlah sampel dan $\mathrm{k}$ adalah jumlah variabel independen termasuk konstanta. Uji ini dilakukan untuk mengetahui pengaruh dari tiap-tiap variabel bebas (PMA\$, PMDN, Angkatan Kerja, Belanja Langsung Modal Pembangunan, Ekspor (XPOR\$), dan Krisis Keuangan Global (DKK)) terhadap variabel terikat (PDRB Atas Harga Konstan/PDRBHK). Apabila nilai $p$-value (probabilitas) < tingkat signifikansi 5\% atau 10\% dapat disimpulkan terdapat pengaruh yang signifikan dari masing-masing variabel bebas terhadap variabel terikat.

\section{Pengaruh Penanaman Modal Asing (PMA) terhadap PDRB}

Hasil olah data Eviews menunjukkan bahwa variabel PMA memiliki t-hitung sebesar 2,272248 dan probabilitas sebesar 0,0423. Dengan tingkat keyakinan 95\%, 90\% ( $\alpha=5 \%, 10 \%)$ maka variabel PMA secara individu signifikan mempengaruhi pertumbuhan ekonomi (PDRB) di Provinsi Riau. Nilai koefisien regresi 0,021 menunjukkan bahwa PMA berpengaruh positif terhadap pertumbuhan ekonomi yang diukur dengan PDRB ADHK di Provinsi Riau.

\section{Pengaruh Penanaman Modal Dalam Negeri (PMDN) terhadap PDRB}

Hasil analisis olah data menunjukkan bahwa variabel PMDN memiliki t-hitung sebesar 2,278977 dan probabilitas sebesar 0,0418. Dengan tingkat keyakinan 95\%, $90 \%(\alpha=5 \%, 10 \%)$ maka variabel PMDN secara individu signifikan mempengaruhi PDRB ADHK di Provinsi Riau. Nilai koefisien regresi sebesar 0.024 menunjukkan bahwa PMDN berpengaruh positif terhadap PDRB ADHK di Provinsi Riau.

\section{Pengaruh Angkatan Kerja terhadap PDRB}

Hasil analisis EViews menunjukkan bahwa variabel angkatan kerja memiliki thitung sebesar 7,813845 dan probabilitas sebesar 0,0000 . Dengan taraf nyata $5 \%$ maupun $10 \%$ variabel angkatan kerja secara individu signifikan mempengaruhi PDRB ADHK di Provinsi Riau. Nilai koefisien regresi sebesar 0,626 menunjukkan bahwa PMDN berpengaruh positif terhadap PDRB ADHK di Provinsi Riau. 


\section{Pengaruh Belanja Langsung Pemerintah untuk Modal Pembangunan (BLMP) terhadap PDRB}

Hasil analisis Eviews menunjukkan bahwa variabel BLMP memiliki t-hitung sebesar $-1,303700$ dan probabilitas sebesar 0,2168 . Dengan taraf nyata $5 \%$ maupun $10 \%$ variabel BLMP secara individu tidak signifikan mempengaruhi PDRB ADHK di Provinsi Riau.

\section{Pengaruh Ekspor (XPOR) terhadap PDRB}

Hasil analisis EViews menunjukkan bahwa variabel Ekspor memiliki t-hitung sebesar 3,444595 dan probabilitas sebesar 0,0049. Dengan taraf nyata 5\% maupun $10 \%$ variabel Ekspor secara individu signifikan mempengaruhi PDRB ADHK di Provinsi Riau. Nilai koefisien regresi sebesar 0.1452 menunjukkan bahwa Ekspor berpengaruh positif terhadap PDRB ADHK di Provinsi Riau.

\section{Pengaruh Variabel Dummy Krisis Keuangan Global (DKK) terhadap PDRB}

Hasil analisis EViews menunjukkan bahwa berdasarkan probabilitasnya, variabel DKK significance dengan P-value 0,0002 atau probabilitas jauh di bawah 0,05 , maka adanya Krisis (DKK) mempengaruhi perekonomian di provinsi Riau tahun 2008-2018. Nilai koefisien regresi sebesar 0,254 menunjukkan bahwa adanya krisis menyebabkan nilai PDRB ADHK di Provinsi Riau berbeda nyata positif dibanding sebelum krisis keuangan global. Hal ini dapat terjadi karena adanya mekanisme pengalihan Penanaman Modal Asing dari negara yang mengalami krisis keuangan global yaitu Eropa dan Amerika ke negera-negara emerging market termasuk Indonesia. Disamping itu kinerja ekspor mengalami peningkatan dalam bentuk perluasan penetrasi ekspor ke negara tujuan ekspor di kawasan lain selain Eropa dan Amerika serta adanya keuntungan ekonomi karena nilai kurs Dollar dan Pound sterling yang melemah akibat krisis subprime mortgage yang terjadi di Eropa dan Amerika sehingga PDRB Riau masih dapat tumbuh positif.

Uji statistik secara serentak ditunjukkan oleh perbandingan nilai $F$ hitung dengan $\mathrm{F}$ tabel atau dengan melihat nilai probabilitas $\mathrm{F}$ hitung. $\mathrm{F}$ tabel dengan $\mathrm{df}=$ (k-1, n-k), dengan derajat kepercayaan sebesar 95 persen. Berdasarkan hasil analisis EViews diperoleh nilai $F$ hitung sebesar 133,1873 dan probabilitas $F$ sebesar 0,000000 . Dalam taraf nyata $5 \%$ maka uji $F$ dinyatakan signifikan, $p$-value $(0,000000)<\alpha=0,05$. Sehingga dapat disimpulkan bahwa seluruh variabel bebas secara bersama-sama berpengaruh signifikan terhadap variabel terikat. Keenam variable PMA, PMDN, AK, BLMP, Ekspor dan dummy DKK secara bersama-sama dapat menjelaskan perekonomian di Provinsi Riau.

Pengecekan Regresi Lancung (Spurious Regression), menurut Kao (1999) dan Winarno (2015) bahwa ada tidaknya regresi lancung atau regresi yang tidak bermakna dapat dilihat dari beberapa karakteristik output analisis yaitu memiliki koefesien determinasi (nilai $F$ ) tinggi, memiliki nilai $R^{2}$ tinggi dan memiliki nilai signifikansi parsial (t) tinggi serta nilai $D W$ yang rendah $(D W<0,5)$. Berdasarkan output regresi model log-log linier diperoleh nilai $R^{2}$ tinggi, banyak variabel 
independen yang signifikan namun nilai DW yang relatif besar $(D W=2,226>0,5$ ) sehingga dapat disimpulkan output regresi yang dihasilkan model terbebas dari karakteristik regresi lancung (spurious).

Semua pengujian model regresi berganda telah dilakukan, ternyata menunjukkan bahwa model regresi yang digunakan sudah baik, terbebas dari penyakit asumsi Klasik Gauss Markov, terbebas dari spurious regression dan data time series yang stationer.

\section{Interpretasi Ekonomi dari Persamaan}

Persamaan yang diperoleh diatas diinterpretasikan pada sub bagian ini. Pertama, nilai konstanta sebesar 4,899 menunjukkan bahwa jika variabel-variabel independen dianggap konstan, maka nilai rata-rata PDRB adalah sebesar $4,8 \%$. Angka sebesar itu dipengaruhi oleh variabel-variabel lain di luar model seperti tingkat konsumsi rumah tangga swasta dan konsumsi pemerintah. Variabel tingkat konsumsi baik konsumsi Rumah Tangga (swasta) dan konsumsi Pemerintah merupakan salah satu komponen pembentuk nilai PDRB pada fungsi deterministik PDRB. Jika konsumsi meningkat maka akan menggerakkan kurva Aggregate Demand ke atas sehingga pertumbuhan PDRB juga akan meningkat.

Kedua, koefisien dari variabel realisasi Penanaman Modal Asing (PMA) adalah 0,021 dan nilai tersebut adalah positif. Peningkatan realisasi PMA berpengaruh positif terhadap PDRB Provinsi Riau secara signifikan. Jika realisasi PMA naik 1\%, maka PDRB provinsi Riau naik $0,021 \%$. Hal ini menjadi tantangan bagi pemerintah provinsi Riau, untuk mengoptimalkan peningkatan PMA dengan terus memberikan iklim investasi yang lebih kondusif. Beberapa diantaranya dengan melakukan efisiensi perijinan atau regulasi kebijakan di bidang investasi yang sudah dijalankan dengan membentuk Mall Pelayanan Terpadu Satu Pintu, Penyelesaian RTRW, jaminan hukum dan ketertiban berusaha, atau bahkan memberikan insentif dan atau tax holiday bagi investasi yang padat karya, sehingga dapat memberikan lapangan pekerjaan. Data dari Dinas Penanaman Modal dan Pelayanan Terpadu Provinsi Riau bahwa peringkat PMA di Riau tahun 2018 menduduki peringkat ketiga di Sumatera nilai Investasi US\$1.032,88 juta atau senilai Rp. 13,84 triliun. Dilihat dari tingkat daya saing berusaha sebagai salah satu indikator faktor penarik PMA maka hasil penelitian Lee Kuan Yew School of Public Policy (2016) menunjukkan bahwa peringkat Riau terus membaik setiap tahun di tingkat Nasional yaitu peringkat 15 (2016), 16 (2017),13 (2018) dan 11 (2019).

Hasil temuan PMA berpengaruh langsung terhadap pertumbuhan PDRB ini sejalan dengan hasil penelitian yang dilakukan Religi dan Purwanti (2017) bahwa PMA berpengaruh positif dan signifikan terhadap pertumbuhan ekonomi di kabupaten dengan tipe Klassen I (pendapatan per kapita dan pertumbuhan ekonomi di atas median nasional). Hasil temuan serupa juga sejalan dengan Salebu (2014) yang menyatakan bahwa penanaman modal asing atau Foreign Direct Investment (variabel LFDI) berpengaruh signifikan terhadap pertumbuhan ekonomi (LGDP).

Capaian realisasi PMA di Riau selama periode 2010-2019 yang cenderung menggambarkan trend yang naik terutama PMA pada proyek di sektor sekunder 
yang relatif stabil meningkat dan lebih besar nilainya dibanding sector primer dan tersier. Industri pada proyek sekunder ini yaitu industri makanan, tekstil, kayu, kertas, kimia dasar, mineral non logam, logam dasar dan alat angkut/transportasi. Rata-rata realisasi proyek PMA per sektor dengan proyek fisik salah satunya berupa pendirian perusahaan pada periode tersebut mencapai masing-masing 32 (primer), 101 (sekunder) dan 48 (tersier) unit proyek. Secara keseluruhan selama periode tersebut sudah teralisir proyek PMA sebanyak 2.208 unit proyek. Kondisi dukungan iklim investasi yang kondusif dan kemudahan perijinan tetap harus dipertahankan bahkan ditingkatkan oleh semua stakeholders di Riau agar pencapaian dampak luas investasi PMA terhadap pertumbuhan ekonomi Riau terwujud dengan baik.

Kemudian, ketiga, koefisien dari variabel realisasi Penanaman Modal Dalam Negeri (PMDN) adalah 0,024 dan bernilai positif. Peningkatan realisasi PMDN berpengaruh positif terhadap pertumbuhan ekonomi provinsi Riau secara signifikan. Hasil temuan ini sejalan dengan penelitian yang dilakukan oleh Saptomo (2008) dan Jufrida et al., (2016), bahwa investasi swasta dalam negeri berpengaruh positif dan signifikan terhadap pertumbuhan ekonomi (PDRB). Jika realisasi PMDN naik 1\%, maka pertumbuhan ekonomi Riau yang diukur dengan PDRB ADHK naik menjadi $0,024 \%$. Nilai PMDN yang ditanamkan di provinsi Riau selama periode pengamatan lebih rendah dibanding PMA dari sisi besarannya. Yang perlu mendapat perhatian berkenaan dengan PMDN di Riau adalah aspek daya serap tenaga kerja. Hal itu penting mengingat masih begitu banyaknya angkatan kerja yang membutuhkan pekerjaan di Riau.

Di sisi lain, lingkungan berusaha di level provinsi tetap ikut menentukan iklim usaha di ranah lokal maupun di level kewilayahan provinsi secara umum, terkait dengan faktor eksternal, economies of scale, regional-specific, dan peran Pemda untuk fasilitasi kebijakan, koordinasi dan pengendalian aktivitas penanaman modal di wilayah Provinsi. Semua itu mendorong perlunya pemetaan iklim usaha di level Provinsi, termasuk di dalamnya peran pemerintahan Provinsi. Dalam kerangka pembangunan secara keseluruhan, investasi swasta, PMDN menghasilkan banyak dampak ganda (multiplier effects) dan memberi manfaat bagi banyak pihak: perusahaan, masyarakat dan pemerintah. Laju pertambahan investasi PMDN dan tingkat produktivitas yang dihasilkannya akan mendorong tinggi dan luasnya jangkauan dampak yang ditimbulkan.

Jika dilihat dari perkembangan penanaman PMDN untuk proyek per sektor dibanding PMA terlihat memiliki pola yang berbeda. Pada periode 2010-2014 pertumbuhan proyek PMDN relatif kecil namun mulai dari 2015-2017 mengalami kenaikan cukup pesat untuk semua sektor baik primer, sekunder maupun tersier. Pola penanaman modal PMDN mulai turun drastis di tahun 2018-2019 untuk proyek sektor primer dan sekunder sedangkan sektor tersier di tahun 2019 menunjukkan peningkatan yang cukup besar yaitu pada industri konstruksi, perdagangan, hotel dan restoran, transportasi dan telekomunikasi, perumahan dan jasa lainnya. Ratarata realisasi proyek PMDN per sektor dengan proyek fisik salah satunya berupa pendirian perusahaan pada periode tersebut mencapai masing-masing 40 (primer), 55 (sekunder) dan 45 (tersier) unit proyek. Secara keseluruhan selama periode tersebut sudah teralisir proyek PMDN sebanyak 1.405 unit proyek. Dilihat dari 
peringkat daerah tujuan investasi PMDN selama 5 tahun terakhir maka provinsi Riau menduduki capaian peringkat yang baik di skala Nasional maupun Sumatera. Peringkat realisasi investasi PMDN menurut BKPM Riau (Dinas Penanaman Modal dan Pelayanan Terpadu Satu Pintu Provinsi Riau, 2020) secara berturut-turut di tingkat Sumatera adalah peringkat 7 (2015/nilai PMDN sebesar Rp. 9,9 triliun), peringkat 10 (2016/nilai PMDN sebesar Rp. 6,6 triliun), peringkat 2 (2017/nilai Rp. 10,8 triliun), peringkat 3 (2018/nilai Rp. 9,05 triliun) dan peringkat 1 (2019/nilai Rp. 26,29 triliun).

Keempat, koefisien variabel dari Angkatan Kerja (AK) adalah 0,626 dan nilai ini adalah positif. Pertumbuhan angkatan kerja berpengaruh positif terhadap pertumbuhan ekonomi provinsi Riau secara signifikan. Jika AK naik 1\%, maka pertumbuhan ekonomi Riau naik menjadi $0,626 \%$. Angka elastisitas angkatan kerja ini memberikan sinyal bahwa kontribusi angkatan kerja di Riau bagi pertumbuhan ekonomi (PDRB ADHK) Riau cukup signifikan. Hal ini disebabkan karena banyaknya industri di Riau yang bersifat padat karya dan banyaknya penduduk yang bekerja pada sektor primer (pertanian) dan tersier (perdagangan).

Hasil regresi yang menunjukkan koefisien elastisitas yang tinggi dari angkatan kerja dalam mempengaruhi pertumbuhan ekonomi Riau ini seyogyanya tidak selalu diinterpretasikan secara matematis, karena meskipun angkatan kerja Riau secara nominal meningkat dari tahun ke tahun tetapi angkatan kerja tersebut kualitasnya masih perlu ditingkatkan untuk memberikan kontribusi dalam pembentukan PDRB mengingat jumlah angkatan kerja dengan tingkat pendidikan tamatan Diploma dan Sarjana masih relatif kecil. Hasil penelitian Religi dan Purwanti (2017) menunjukkan bahwa tenaga kerja dengan tamatan SMA ke bawah tidak berpengaruh signifikan terhadap pertumbuhan ekonomi di tiap tipe kabupaten/kota sehingga perlu dilakukan upskill atau upgrade angkatan kerja agar dapat menamatkan tingkat pendidikan yang lebih tinggi.

Kelima, koefesien variabel dari Belanja Langsung Modal Pemerintah (BLMP) adalah $-0,025$. Uji t dilakukan terhadap pengaruh variabel belanja modal pemerintah terhadap perubahan PDRB. Nilai t hitung adalah -1.3037 dan tidak signifikan. Dari uji t, kita dapat menyimpulkan bahwa variabel belanja modal pemerintah tidak signifikan berpengaruh terhadap perubahan PDRB. Artinya kita percaya bahwa dari kasus pada Provinsi Riau dimana belanja modal pemerintah tidak berpengaruh terhadap perubahan PDRB. Dengan demikian, kesimpulan ini berbeda dengan hipotesis penelitian. Tanda parameter estimasi menunjukkan bahwa koefisien belanja modal pemerintah bertanda negatif. Hal ini berbeda dengan estimasi tanda positif pada hipotesis penelitian (expected sign). Kita tidak mengartikan slope koefisien belanja modal pemerintah karena uji statistik tidak menunjukkan signifikan. Dengan melihat kepada tujuan penelitian, kita dapat menyimpulkan besarnya belanja modal pemerintah tidak berpengaruh atau mempunyai pengaruh negatif terhadap perubahan PDRB.

Hasil temuan BLMP tidak berpengaruh langsung terhadap pertumbuhan PDRB ini sejalan dengan hasil penelitian yang dilakukan Anasmen (2009), yang menyatakan Belanja Modal Pemerintah tidak signifikan mempengaruhi 
pertumbuhan Produk Domestik Regional Bruto provinsi Sumatera Barat. Hal ini disebabkan oleh belanja modal pemerintah provinsi tidak berpengaruh cukup besar pada pertumbuhan Produk Domestik Regional Bruto. Dari analisis belanja modal provinsi Riau untuk tahun 2000-2018, lebih banyak dialokasikan kepada belanja yang tidak terkait langsung dengan infrastruktur (kurang produktif). Belanja langsung modal lebih dialokasikan pada belanja yang bersifat pemeliharaan, peralatan aparatur negara, kantor dan belanja modal yang berkarakteristik einmalig yaitu belanja modal yang hanya dilakukan satu kali dan tidak berkelanjutan seperti belanja untuk rumah dinas, asrama, gedung/balai pemerintah daerah, AC, genset, generator, penerangan listrik dan pendukung operasional lainnya karena hanya akan memberikan beban (cost centre) tanpa ada efek multiplier yang menghasilkan pendapatan bagi perekonomian. Disisi lain pertumbuhan PDRB lebih besar di sektor pertanian namun tidak mempunyai hubungan yang signifikan dengan Belanja Modal Pemerintah.

Hasil penelitian dapat memotret pola pemda Riau dalam menyerap APBD-nya, proporsionalitas pengalokasian belanja langsung dan tidak langsung dan aspek cepat atau lambatnya waktu yang diperlukan dalam penyerapan belanja daerah. Pola spending pemerintah Riau selama periode pengamatan didominasi oleh belanja tidak langsung rutin dengan rata-rata $43,31 \%$ dan belanja langsung modal pemerintah hanya 30,92\%. Lebih detail bahwa belanja rutin untuk aparatur berada pada kisaran $29,31 \%-62 \%$ dengan beberapa periode yang menunjukkan pola belanja rutin diatas $50 \%$. Sementara dari nilai indeks keserasian aktivitas belanja modal untuk infrastruktur dan pelayanan publik sepanjang periode 2000-2018 kurang dari 50\% bahkan pada tahun 2014 hanya tercapai 11\% dan 2018 (12\%). Hal ini sejalan dengan temuan yang dilakukan oleh Mardiasmo (2018) yang menemukan bahwa pola spending sebagian besar pemerintah provinsi di Indonesia rata-rata alokasi dana selama ini untuk aparatur pemerintah, operasional kantor, pemeliharaan masih tergolong tinggi dibanding alokasi dana untuk pelayanan pembangunan atau publik seperti kesehatan, tenaga kerja, kesejahteraan sosial, kependudukan, KB, pemberdayaan perempuan, hukum, keamanan, penelitian dan IPTEK. Alokasi dari kapasitas fiskal untuk pembangunan biasanya hanya mendapatkan sisa anggaran atau dipenuhi setelah alokasi untuk belanja operasional terpenuhi (Mardiasmo, 2018). Indikator pola spending performance selain kualitas belanja daerah dan APBD Riau yang masih lemah dengan salah satu indikasi belanja tidak langsung selalu lebih besar dari belanja langsung dan penyerapan belanja daerah yang relatif rendah, tingkat penyerapan belanja daerah yang relatif rendah terutama untuk belanja modal (belanja barang dan jasa yang terkait dengan public service delivery).

Hasil penelitian menunjukkan belanja Modal pemerintah sangat dibatasi oleh sumber penerimaan yang lebih banyak berasal dari pemerintah pusat. Ditambah lagi, sumber penerimaan tersebut lebih banyak tersedot untuk belanja rutin sehingga alokasi anggaran untuk Belanja Modal Pemerintah menjadi terbatas. Dengan Belanja Modal Pemerintah yang tersedia, seharusnya dialokasikan secara tepat kepada proyek investasi yang mempunyai dampak multiplier yang besar terhadap pertumbuhan ekonomi seperti pembangunan jalan ke sentra produksi. 
Indeks keserasian aktivitas belanja modal untuk infrastruktur dan pelayanan publik sepanjang periode 2000-2018 kurang dari 50\%. Karena semakin besar belanja tidak langsung yang dianggarkan tidak terkait dengan program atau kegiatan pembangunan maka anggaran untuk pembangunan juga semakin berkurang akibatnya pola spending untuk pembangunan ekonomi kurang berkualitas. Belanja rutin mempunyai persentase terhadap PDRB lebih besar $(0,66 \%)$ dibandingkan dengan belanja pembangunan $(0,51 \%)$. Hal ini menunjukkan bahwa belanja pemerintah daerah terlihat lebih ekspansif, tetapi peningkatan ini didominasi oleh belanja rutin yang digunakan sebagian besar untuk belanja konsumtif.

Keenam, koefisien variabel Ekspor (XPOR) adalah 0,1452 dan nilai ini adalah positif. Hal ini meenunjukkan pertumbuhan ekspor berpengaruh positif terhadap pertumbuhan PDRB Provinsi Riau secara signifikan. Jika ekspor naik 1\%, maka pertumbuhan PDRB Riau naik menjadi 0,14\%. Angka elastisitas ekspor ini memberikan sinyal bahwa kontribusi ekspor di Riau bagi pertumbuhan ekonomi (PDRB ADHK) Riau cukup signifikan. Hasil penelitian ini sejalan dengan temuan Asbiantari et al., (2016), bahwa ekspor sektor industri berpengaruh positif dan signifikan terhadap pertumbuhan ekonomi Indonesia baik dalam jangka pendek maupun jangka panjang. Hasil temuan sejenis dinyatakan oleh Asiyan (2013), bahwa ekspor signifikan berpengaruh positif terhadap PDRB di provinsi Jawa Timur. Dilihat dari tingkat pertumbuhan ekspor, rata-rata tahunan selama periode 200-2018, ekspor Riau tumbuh sebesar 4,70\%. Pertumbuhan ekspor ini perlu dicermati untuk dapat ditingkatkan lagi dengan menciptakan nilai tambah ekspor komoditas berbasis pertanian dalam arti luas, hilirisasi produk maupun industri ekonomi kreatif mengingat ekspor migas Riau sudah menunjukkan penurunan alamiah. Disamping itu negara tujuan ekspor perlu diperluas ke kawasan atau negara lain untuk menghindari tingkat konsentrasi dan ketergantungan pada kawasan tertentu. Hal ini diperlukan untuk memitigasi jika terjadi krisis ekonomi di kawasan negara tertentu tidak mengganggu kinerja ekspor Riau. Diharapkan dengan upaya yang demikian maka kinerja ekspor naik sehingga PDRB juga akan naik.

Terakhir, ketujuh, koefisien variabel dummy krisis keuangan global (DKKt) adalah 0,2541 dan nilai ini adalah positif. Dummy krisis keuangan (DKKt) menunjukkan hasil yang signifikan pada level $5 \%$. Variabel dummy ini menunjukkan bukti adanya perbedaan pengaruh antara masa sebelum krisis (2000-2007) dan masa sesudah krisis (2008-2018). Hasil signifikan dengan tanda parameter positif $(0,254)$ membuktikan bahwa pengaruh keadaan krisis keuangan sangat kecil perannya dalam model. Variabel dummy dibaca sebagai nilai perbedaan rata-rata PDRB antara nilai PDRB sebelum krisis dan setelah krisis. Variabel dummy tidak boleh dibaca sebagai pengaruh naik turun PDRB sebagai akibat perbedaan kondisi variable dummy. 
Tabel 3. Nilai Perubahan Pertumbuhan PDRB Sebelum dan Sesudah Krisis Keuangan Global

\begin{tabular}{lcccc}
\hline Variabel Tergantung & $\begin{array}{c}\text { Intersep } \\
\boldsymbol{\beta}_{0}\end{array}$ & $\begin{array}{c}\text { Koefesien } \\
\text { Parameter } \\
\text { Sebelum } \\
\text { Krisis } \beta_{0}\end{array}$ & $\begin{array}{c}\text { Koefisien } \\
\text { Parameter } \\
\text { Sesudah Krisis } \\
\boldsymbol{\beta}_{0}+\boldsymbol{\beta}_{1}\end{array}$ & $\begin{array}{c}\text { Nilai } \\
\text { Perubahan } \\
\text { pertumbuhan } \\
\text { PDRB Akhir }\end{array}$ \\
\hline $\begin{array}{l}\text { PDRB ADHK } \\
\text { Sebelum Krisis }\end{array}$ & 4,89 & $\begin{array}{c}4,89(\text { sama } \\
\left.\text { dengan } \beta_{0}\right)\end{array}$ & 0 & $4,89(\%)$ \\
$\begin{array}{l}\text { PDRB ADHK } \\
\text { Sesudah Krisis }\end{array}$ & 4,89 & 0 & $\begin{array}{c}4,89+0,25\left(\beta_{0}\right. \\
\left.+\beta_{1}\right)\end{array}$ & $5,14(\%)$ \\
Sumber: Hasil olah data Eviews & & & &
\end{tabular}

Dengan menganggap semua variabel lain konstan, maka terdapat perbedaan rata-rata tingkat PDRB Riau sebelum dan sesudah krisis keuangan. Nilai pertumbuhan PDRB berbeda sedikit secara nyata ketika terjadi krisis keuangan yaitu $5,14 \%$ dibandingkan dengan sebelum krisis sebesar 4,89\%. Krisis keuangan global pada pada 2008 ditandai dengan kasus subprime mortgage ternyata berimbas ke krisis sektor finansial yang lebih dalam yaitu runtuhnya perusahaan jasa keuangan internasional yang memiliki reputasi tidak diragukan seperti Lehman Brothers, AIG, Fannie Mae, Freddie Mac. Kondisi ini ternyata semakin memburuk, meluas, dan berkepanjangan karena tidak hanya dirasakan oleh perekonomian Amerika tetapi juga dirasakan di berbagai belahan dunia lainnya. Beberapa diantaranya adalah tumbangnya harga-harga saham hampir di seluruh belahan dunia serta kebangkrutan banyak lembaga keuangan baik di negara maju maupun di negara berkembang.

Untuk kasus Indonesia, krisis keuangan yang berskala global tidak terlalu berdampak baik pada melemahnya sektor keuangan maupun pada sektor riil. Sektor rill domestik yang berhubungan dengan sektor keuangan domestik, serta dengan sektor riil dan keuangan internasional melalui aktivitas ekspor impor dan pembiayaan sudah dapat merasakan dampak krisis keuangan dan pelambatan ekonomi global (Sugema, 2013). Untuk kasus Riau, terdapat perbedaan rata-rata pertumbuhan PDRB yang lebih besar sesudah krisis pada periode pengamatan dapat dipahami karena pertama, Riau tidak terlalu bergantung pada ekspor dikarenakan pangsa ekspor Riau tidak mencapai setengah dari PDRB Sumatera dan sumbangan Ekspor terhadap PDRB Riau kurang dari 50 persen serta ekspor Riau tidak terkonsentrasi pada kawasan Amerika dan Eropa yang terdampak krisis. Justru setelah krisis nilai ekspor meningkat karena adanya perubahan perluasan penetrasi ekspor ke kawasan lain yaitu negara-negara di kawasan Asia (69,33\%) seperti negara Tiongkok, India, Malaysia, Pakistan, Korea Selatan, dan lain-lain sehingga mendapatkan devisa hasil ekspor yang lebih besar. Kedua, sektor perbankan dan sektor finansial Riau tidak mengalami dampak finansial karena tingkat kebergantungannya tidak dalam dan tidak memiliki outstanding kredit luar negeri dalam jumlah dana yang besar atau tidak memiliki bentuk portofolio investasi berbasis subprime mortgage. Ketiga, dalam konteks nasional, penurunan bursa juga tidak akan terlalu memberikan pengaruh yang nyata pada gejolak ekonomi dalam negeri karena pelaku pasar saham hanyalah $0,5 \%$ dari penduduk Indonesia. Keempat, pelaku eksportir Riau mendapat keuntungan ekonomi yang bersumber 
dari devisa dalam bentuk mata uang hard currency seperti USD dan GBP yang melemah sehingga eksportir mendapat devisa tersebut dalam jumlah yang lebih banyak. Kelima, dampak kelambanan krisis keuangan sangat singkat sekitar 1 tahun karena perekonomian Indonesia sudah menunjukkan perbaikan ekonomi di Triwulan II/2009 (Bank Indonesia, 2009). Terakhir, Riau dapatlah dikatakan sebagai self sustaining regional economy karena potensi pasar lokal dan antar daerah yang sangat besar sehingga walaupun pasar luar negeri sedang lesu, pasar antar daerah sudah sangat besar.

\section{KESIMPULAN}

Variabel PMA, PMDN, Angkatan Kerja, Ekspor dan Krisis Keuangan Global signifikan berpengaruh positif sedangkan Belanja Langsung Modal Pemerintah tidak signifikan berpengaruh positif terhadap pertumbuhan PDRB. Hal ini didukung oleh uji statistik dimana hanya variabel belanja langsung modal pemerintah saja di Provinsi Riau tidak berpengaruh terhadap pertumbuhan PDRB. Dengan demikian hipotesis penelitian, dimana Belanja Langsung Modal Pemerintah, berpengaruh positif dan signifikan terhadap pertumbuhan Produk Domestik Regional Bruto di Provinsi Riau tahun (2000-2018) tidak sesuai dengan hasil penelitian. Ini berarti, hipotesis penelitian ditolak berdasarkan hasil analisis regresi. Hal ini disebabkan oleh belanja modal pemerintah provinsi tidak berpengaruh cukup besar pada pertumbuhan Produk Domestik Regional Bruto. Karena semakin besar belanja tidak langsung yang dianggarkan tidak terkait dengan program atau kegiatan pembangunan maka anggaran untuk pembangunan juga semakin berkurang akibatnya pola spending untuk pembangunan ekonomi kurang berkualitas. Peran belanja pembangunan dalam pembentukan PDRB Riau sangat kecil. Hal ini menunjukkan bahwa belanja pemerintah daerah didominasi oleh belanja rutin yang digunakan sebagian besar untuk belanja konsumtif aparatur daerah. Dengan demikian dapat kita simpulkan, pengeluaran belanja modal tidak dialokasikan lebih besar kepada pembangunan infrastruktur dan pelayanan publik yang dapat memberikan multiplier effect yang lebih luas terhadap pembangunan ekonomi.

Sementara itu faktor-faktor yang mempengaruhi pertumbuhan ekonomi provinsi Riau selama tahun pengamatan 2000-2018 adalah realisasi nilai PMA, realisasi nilai PMDN, Angkatan Kerja (AK) dan Ekspor. Hasil analisis mengenai pengaruh PMA, PMDN, Angkatan Kerja dan ekspor daerah terhadap pertumbuhan ekonomi provinsi Riau menunjukkan hubungan yang positif signifikan. Penambahan variabel dummy krisis juga menunjukkan pengaruh yang positif signifikan terhadap pertumbuhan ekonomi. Adanya krisis keuangan global tahun 2008 menyebabkan perbedaan PDRB yang nyata secara positif meskipun dengan nilai yang kecil antara keadaan sebelum dan sesudah terjadinya krisis keuangan global yang diakibatkan karena krisis berlangsung singkat dan ketidaktergantungan secara ekonomi maupun ketiadaan eksposur portofolio berbasis sekuritas subprime mortgage yang dipegang oleh pelaku bisnis di Provinsi Riau. 


\section{DAFTAR PUSTAKA}

(1) Anasmen. (2009). Pengaruh Belanja Modal Pemerintah Terhadap Pertumbuhan Ekonomi Di provinsi Sumatera Barat Tahun 2000-2006 [Master thesis]. Fakultas Ekonomi, Universitas Indonesia. http://lontar.ui.ac.id/file?file=digital/20237725T+28793-Pengaruh+belanja-full+text.pdf

(2) Asbiantari, D.R., Hutagaol, M.P., \& Asmara, A. (2016). Pengaruh Ekspor terhadap Pertumbuhan Ekonomi Indonesia. Jurnal Ekonomi dan Kebijakan Pembangunan, 5(2), 10-31. https://doi.org/10.29244/jekp.5.2.10-31

(3) Asiyan, S. (2013). Pengaruh Penanaman Modal Dalam Negeri, Penanaman Modal Asing, dan Ekspor terhadap Pertumbuhan Ekonomi Jawa Timur. Jurnal Pendidikan Ekonomi (JUPE), 1(3). https://jurnalmahasiswa.unesa.ac.id/index.php/jupe/article/view/4024

(4) Bank Indonesia. (2009). Laporan Perekonomian Indonesia Bab II Pemulihan Ekonomi Global dan tantangan Ke Depan. Bank Indonesia.

(5) Bank Indonesia. (2019). Kajian Ekonomi dan Keuangan Regional. Bank Indonesia.

(6) Dinas Penanaman Modal dan Pelayanan Terpadu Satu Pintu Provinsi Riau. (2020, March). Realisasi Penenaman Modal PMDN - PMA Provinsi Riau Tahun 2019. Dinas Penanaman Modal dan Pelayanan Terpadu Satu Pintu Provinsi Riau. http://dpmptsp.riau.go.id/media/file/95950969215REALISASI TW IV 2019.pdf

(7) Gujarati, D. (2010). Basic Econometric (Eight Edition). McGraw-Hill.

(8) Ishise, H., \& Sawada, Y. (2009). Aggregate returns to social capital: Estimates based on the augmented augmented-Solow model. Journal of Macroeconomics, 31(3), 376-393. https://doi.org/10.1016/j.jmacro.2008.08.002

(9) Jufrida, F., Syechalad, M.N., \& Nasir, M. (2016). Analisis Pengaruh Investasi Asing Langsung (FDI) dan Investasi Dalam Negeri terhadap Pertumbuhan Ekonomi Indonesia. Jurnal Perspektif Ekonomi Darussalam, 2(1). https://doi.org/10.24815/iped.v2i1.6652

(10) Kao, C. (1999). Spurious regression and residual-based test for cointegration panel data. Journal of Econometrics, 90(1), 1-44.

https://econpapers.repec.org/RePEc:eee:econom:v:90:y:1999:i:1:p:1-44

(11) Kuncoro, M. (2004). Ekonomi Pembangunan. AMP YKPN.

(12) Lee Kuan Yew School of Public Policy. (2016). Analisis Daya Saing Provinsi-provinsi di Indonesia. Lee Kuan Yew School of Public Policy, National University of Singapore. http://feb.unila.ac.id/wp-content/uploads/2016/08/LampungPresentation.pdf

(13) Mankiw, N.G. (2012). Macroeconomics (8th edition). Worth Publishers.

(14) Mardiasmo. (2018). Otonomi dan Manajemen Keuangan Daerah. Andi IKAPI.

(15) McQuinn, K., \& Whelan, K. (2007). Solow (1956) as a Model of Cross-Country Growth Dynamics. Central Bank of Ireland. https://researchrepository.ucd.ie/handle/10197/234

(16) Oluwatobi, S., \& Ogunrinola, O. (2011). Government Expenditure on Human Capital Development: Implications for Economic Growth in Nigeria. Jounal of Sustainable Development, 4(3), 72-80. https://doi.org/10.5539/jsd.v4n3p72

(17) Religi, S., \& Purwanti, D. (2017). Analisis Perbandingan Pengaruh Modal dan Tenaga Kerja terhadap Pertumbuhan Ekonomi antar Tipe Klasifikasi Kabupaten/Kota di Pulau Jawa Tahun 2008-2013. Jurnal Aplikasi Statistika \& Komputasi Statistik, 9(2), 67-78.

https://jurnal.stis.ac.id/index.php/jurnalasks/article/view/149 
(18) Salebu, J.B. (2014). Pengaruh Penanaman Modal Asing terhadap Pertumbuhan Ekonomi di Indonesia: Analisis Data Panel Periode 1994-2013. Jurnal BPPK: Badan Pendidikan dan Pelatihan Keuangan, 7(2), 135-152. https://jurnal.bppk.kemenkeu.go.id/jurnallbppk/article/view/99

(19) Saptomo, T. (2008). Pengaruh Pertumbuhan Investasi Publik, Investasi Swasta dan Pertumbuhan Penduduk terhadap Pendapatan Kota Semarang [Master thesis]. Universitas Diponegoro. http://eprints.undip.ac.id/19942/

(20) Su, Y., \& Liu, Z. (2016). The impact of foreign direct investment and human capital on economic growth: Evidence from Chinese cities. China Economic Review, 37, 97109. https://doi.org/10.1016/i.chieco.2015.12.007

(21) Sugema, I. (2014). Krisis Keuangan Global 2008-2009 dan Implikasinya pada Perekonomian Indonesia. Jurnal IImu Pertanian Indonesia, 17(3), 145-152. https://journal.ipb.ac.id/index.php/JIPI/article/view/8333

(22) Winarno, W.W. (2015). Analisis Ekonometrika dan Statistik dengan Eviews (5th edition). UPP STIM YKPN. 